\title{
Analisis Mutu Pendidikan Islam (Input, Proses \& Output) (Studi di MI Unggulan Ash-Shiddiqiyyah-3 Purworejo)
}

\author{
Syaefudin \\ Universitas Islam Negeri Sunan Kalijaga Yogyakarta \\ email:syaefudin@uin-suka.ac.id
}

\begin{abstract}
The purpose of this study is to analyze the quality of Islamic education which includes: input, process, output. Specifically on the object of study in this study, namely in SD/MI Unggulan Ash-Shiddiqiyyah-3 di Purworejo. This type of research is qualitative. Using an educational sociology approach. Data collection was obtained directly from informants through interviews, observations, and documentation. Data analysis techniques used are data reduction, data display, data verification, and affirmation of conclusions. An important finding in this study is that SD/MI Unggulan Ash-Shiddiqiyyah-3 di Purworejo cannot be said to be a quality school. Because, the three components of education quality have not been fulfilled, namely: overall input, process, and output.
\end{abstract}

Keywords : Analysis, Education, Quality.

\begin{abstract}
Abstrak
Tujuan dari penelitian ini adalah untuk menganalisis mutu pendidikan islam yang meliputi: input, proses, output. Khususnya pada objek kajian dalam penelitian ini, yaitu di SD/MI Unggulan Ash-Shiddiqiyyah-3 di Purworejo. Jenis penelitian ini adalah kualitatif. Menggunakan pendekatan sosiologi pendidikan. Pengumpulan data diperoleh secara langsung dari informan melalui wawancara, observasi, dan dokumentasi. Teknik analisis data yang digunakan yaitu dengan reduksi data, display data, verifikasi data, dan penegasan kesimpulan. Temuan penting dalam penelitian ini adalah SD/MI Unggulan AshShiddiqiyyah-3 di Purworejo belum dapat dikatakan sebagai sekolah/madrasah yang bermutu. Sebab, belum terpenuhinya ketiga komponen mutu pendidikan, yaitu: input, proses, dan output secara keseluruhan.
\end{abstract}

Kata Kunci : Analisis, Mutu, Pendidikan. 


\section{PENDAHULUAN}

Sudah merupakan pendapat umum, bahwa kemakmuran suatu bangsa berkaitan erat dengan kualitas atau mutu pendidikan bangsa tersebut. Bahakan lebih spesifik lagi, bangsa-bangsa yang berhasil mencapai kemakmuran dan kesejahteraan dewasa ini adalah bangsabangsa yang melaksanakan pembangunan berdasarkan strategi pengembangan sumber daya insani. Artinya, melaksanakan pembangunan nasional dengan menekankan pada pembangunan pendidikan, guna pengembangan kualitas sumber daya manusia.

Pengembangan sumber daya manusia, dari aspek pendidikan berarti mengembangkan pendidikan baik aspek kuantitas maupun kualitas. Aspek kuantitas menekankan pada perluasan lembaga pendidikan, sehingga penduduk memilki akses untuk bisa mendapatkan pelayanan pendidikan tanpa memandang latar belakang kehidupan mereka. Sedangkan dari aspek kualitas, pengembangan kualitas lembaga pendidikan harus selalu ditingkatkan.

Analisis mutu pendidikan berfungsi sebagai proses untuk mengukur kemajuan, penunjang penyusunan rencana, dan memperbaiki atau melakukan penyempurnaan kembali suatu sistem pendidikan. Sedangkan dalam lingkup tujuan pendidikan pada lembaga pendidikan Islam, pendidikan memiliki mandat dan tanggung jawab menciptakan para lulusannya sebagai penggerak kegiatan sosial keagamaan yang dapat menampilkan warna keislaman yang moderat dan bersikap bijak terhadap penyelesaian berbagai problem kemasyarakatan. Dalam konteks inilah, perlu diupayakan peningkatan kapasitas dan kualitas lembaga-lembaga pendidikan Islam pada setiap jalur, jenis, dan jenjang pendidikan serta pemberdayaan masyarakat dalam rangka menciptakan lingkungan pendidikan yang kondusif dan kontributif bagi peningkatan kinerja pendidikan Islam.

Pada kesempatan kali ini, penulis akan menjabarkan tentang bagaimana pimpinan SD/MI Unggulan AshShiddiqiyyah-3 di Purworejo dalam menganalisis lembaganya. Serta, penulis berusaha untuk menyelidiki hingga sejauh mana kualitas mutu lembaga tersebut; sangat bermutu, bermutu, atau belum bermutu.

\section{METODOLOGI PENELITIAN}

Metode yang digunakan dalam penelitian ini adalah metodologi kualitatif. Nana Syaodih Sukmadinata, menyatakan bahwa penelitian kualitatif (qualitative research) adalah suatu penelitian yang ditujukan untuk mendiskripsikan dan menganalisis fenomena, peristiwa, aktifitas sosial, sikap, kepercayaan, persepsi, pemikiran orang secara individu maupun $\quad$ kelompok. $^{1} \quad$ Penulis menggunakan jenis penelitian kualitatif adalah untuk menggambarkan, menganalisa, dan menginterpretasikan kondisi-kondisi berdasarkan data yang penulis dapat secara lebih dalam (Syaefudin, 2018), tentang analisis mutu pendidikan islam (input, proses, output) di SD/MI Unggulan Ash-Shiddiqiyyah-3 di Purworejo.

Data diperoleh secara langsung dari informan melalui wawancara, observasi, dan dokumentasi. Teknik analisis data yang digunakan dalam penelitian ini, yaitu: reduksi data, display data, verifikasi data, dan penegasan kesimpulan. Pengumpulan data adalah proses mengumpulkan berbagai informasi yang diperlukan melalui wawancara, observasi dan dokumentasi. 
Reduksi data, diartikan sebagai proses pemilihan, pemusatan perhatian pada penyederhanaan dan transformasi data kasar yang muncul dari catatancatatan tertulis di lapangan. Display data adalah pendeskripsian sekumpulan informasi tersusun yang memberikan kemungkinan adanya penarikan kesimpulan dan pengambilan tindakan. Verifikasi data merupakan kegiatan interpretasi, yaitu menemukan makna data yang telah disajikan.

\section{HASIL DAN PEMBAHASAN Tantangan dan Peluang Pendidikan Islam}

Dinamika pendidikan Islam di tanah air merupakan tantangan dan sekaligus peluang yang berpotensi pada pencapaian yang lebih baik. Dengan upaya maksimal potensi dan sumber daya yang dimiliki, pengembangan pendidikan Islam setidaknya mempertimbangkan tiga hal utama sebagai indikator keberhasilan, antara lain (1) pemerataan dan perluasan akses pendidikan; (2) peningkatan mutu, relevansi dan daya saing; (3) peningkatan tata kelola, akuntabilitas, dan pencitraan. ${ }^{2}$

Dalam konteks inilah, pendidikan diposisikan tidak saja sebagai human investment yang mempunyai prespektif multidimensional baik sosial, budaya, ekonomi, dan politik, tetapi juga merupakan usaha sadar dan sistematis yang dilakukan manusia agar menyadari posisinya sebagai kholifatullah fil ardhi, yang pada gilirannya akan semakin meningkatkan dirinya untuk menjadi manusia yang bertaqwa, beriman, berilmu, dan beramal sholeh. Sehingga dalam sebuah kredo yang berlaku dalam tradisi Islam, berupa ilmu yang amaliah dan amal yang ilmiah dapat diinternalisasi dalam setiap insan.

$$
\text { Sebagai lembaga-lembaga }
$$
pendidikan yang berbasis pada nilai-nilai agama Islam, pendidikan Islam memiliki mandat dan tanggung jawab menciptakan para lulusannya sebagai penggerak kegiatan sosial keagamaan yang dapat menampilkan warna keislaman yang moderat dan bersikap bijak terhadap penyelesaian berbagai problem kemasyarakatan. Disamping itu lembagalembaga pendidikan agama dan keagamaan Islam dituntut untuk berada di garda depan dalam mengawal gerakan moralitas, lembaga pendidikan Islam setidaknya dapat mengambil peran lebih strategis dalam mengantarkan Indonesia untuk berkompetisi dengan bangsa lain dalam era ekonomi berbasis pengetahuan. Dalam konteks inilah, perlu diupayakan peningkatan kapasitas dan kualitas lembaga-lembaga pendidikan Islam pada setiap jalur, jenis, dan jenjang pendidikan serta pemberdayaan masyarakat dalam rangka menciptakan lingkungan pendidikan yang kondusif dan kontributif bagi peningkatan kinerja pendidikan Islam.

Berbicara pendidikan dalam lingkup kapasitas dan kualitas pendidikan nasional maupun pendidikan Islam, peningkatan mutu pendidikan harus mencakup unsur-unsur: input, proses, dan output pendidikan.

Dari unsur-unsur peningkatan mutu pendidikan di atas, maka dapat dijabarkan sebagai berikut :

\section{a. Input Pendidikan}

Input adalah bahan mentah yang dimasukkan ke dalam trasformasi. Dalam dunia sekolah maka yang dimaksud dengan bahan mentah adalah calon siswa yang baru akan memasuki sekolah. Sebelum memasuki suatu tingkat sekolah (institusi), calon siswa itu dinilai dahulu kemampuannya. Dengan penilaian itu ingin diketahui apakah kelak ia akan mampu mengikuti pelajaran dan

${ }^{2}$ Nizar Ali \& Ibi Syatibi, Manajemen Pendidikan Islam, Bekasi: Pustaka Ishfahan, 2009, hal. 39 
melaksanakan tugas-tugas yang akan diberikan kepadanya. ${ }^{3}$

Komponen-komponen yang harus ada pada Input pendidikan: (1) Memiliki kebijakan, tujuan, dan sasaran mutu yang jelas, (2) Sumber daya tersedia dan siap, (3) Staf yang kompeten dan berdedikasi tinggi, (4) Memiliki harapan prestasi yang tinggi, (5) Fokus pada pelanggan, (6) Input Manajemen. ${ }^{4}$

Input pendidikan adalah segala sesuatu yang harus ada dan tersedia karena dibutuhkan untuk berlangsungnya suatu proses. Segala sesuatu yang dimaksud adalah berupa sumberdaya, perangkat-perangkat lunak serta harapanharapan sebagai alat dan pemandu bagi berlangsungnya proses. ${ }^{5}$ (1) Input sumber daya manusia (kepala sekolah, guru, karyawan, dan siswa), dan Input sumber daya non manusia (peralatan, perlengkapan, uang, bahan, dan lain-lain). (2) Input perangkat lunak yaitu yang meliputi: struktur organisasi sekolah, peraturan perundang-undangan, deskripsi tugas, rencana pendidikan, program pendidikan, dan lain-lain. (3) Input harapan-harapan yang berupa: visi, misi, tujuan, dan sasaran-sasaran yang ingin dicapai oleh sekolah tersebut semakin tinggi tingkat kesiapan input, maka semaki tinggi pula mutu input tersebut.

Pembahasan dan pengertian input pendidikan di atas, dapat disimpulkan bahwa input pendidikan adalah segala sesuatu yang harus tersedia karena dibutuhkan untuk berlangsungnya proses. Segala sesuatu itu berupa sumberdaya manusia dan sumber daya non manusia sebagai berlangsunnya proses pendidikan.

3 Suharsimi Arikonto, Dasar-Dasar Evaluasi Pendidikan, Jakarta: Bumi Aksara, 2009, Edisi Revisi. hal. 4

${ }^{4}$ Imam Machali dan Ara Hidayat, The Hand Book Education Management, Jakarta: Kencana, 2016, hal. 373-374

${ }^{5}$ Ibid., hal. 366

\section{b. Proses Pendidikan}

Proses pendidikan merupakan berubahnya sesuatu menjadi sesuatu yang lain. Sesuatu yang berpengaruh terhadap berlangsungnya proses disebut input, sedangkan sesuatu dari hasil proses disebut output. Dalam pendidikan (tingkat sekolah) proses yang dimaksud adalah proses pengambilan keputusan, proses pengelolaan kelembagaan, proses pengelolaan program, proses belajar mengajar, dan proses monitoring dan evaluasi, dengan catatan bahwa proses belajar mengajar memiliki tingkat kepentingan tinggi dibandingkan dengan proses-proses yang lain. ${ }^{6}$

Proses akan dikatakan memiliki mutu yang tinggi apabila pengkoordinasian dan penyerasian serta pemaduan input (guru, siswa, kurikulum, uang, peralatan, dan lain-lain) dilakukan secara harmonis, sehingga mampu menciptakan situasi pembelajaran yang menyenangkan

(enjoyable learning), mampu mendorong motivasi dan minat belajar, dan benar-benar mampu memberdayakan peserta didik. Kata memberdayakan mempunyai arti bahwa peserta didik tidak sekedar menguasai pengetahuan yang diajarkan oleh gurunya, namun pengetahuan yang mereka dapatkan tersebut juga telah menjadi muatan nurani peserta didik yaitu mereka mampu menghayati, mengamalkan dalam kehidupan seharihari, dan yang terpenting peserta didik tersebut mampu belajar secara terus

6 Imam Machali dan Ara Hidayat, The Hand Book Education Management, Jakarta: Kencana,2016, hal. 366 
menerus atau mampu mengembangkan dirinya. ${ }^{7}$

Pengetian mengenai proses dalam pendidikan dapat ditarik kesimpulan bahwa proses pendidikan adalah tindakan yang dilakukan atau prosedur yang dilaksanakan, misalnya, mengajar, menilai, sistem pengelolaan untuk menggunakan dan mengelola input agar dapat menghasilkan output yang berkualitas.

\section{c. Output Pendidikan}

Yang dimaksud sebagai output atau keluaran adalah bahan jadi yang dihasilkan oleh transformasi. Yang dimaksud dalam pembicaraan ini adalah siswa lulusan sekolah yang bersangkutan. Untuk dapat menentukan apakah seorang siswa berhak lulus atau tidak, perlu diadakan kegiatan penilaian, sebagai alat penyaring kualitas. ${ }^{8}$

Output pendidikan adalah kinerja sekolah. Sedangkan kinerja sekolah itu sendiri adalah prestasi sekolah yang dihasilkan dari proses atau perilaku sekolah. Kinerja sekolah dapat diukur dari kualitasnya, efektivitasnya, produktifitasnya, efesiensinya, inovasinya, kualitas kehidupan kerjanya, dan moral kerjanya. ${ }^{9}$

\section{Output}

pendidikan adalah merupakan kinerja sekolah. Kinerja sekolah adalah prestasi sekolah yang dihasilkan dari proses/perilaku sekolah. Kinerja sekolah dapat diukur dari kualitasnya, produktivitasnya, efektivitasnya, efesiendinya, inovasinya, kualitas kehidupan kerjanya dan moral kerjanya. Khusus yang berkaitan dengan mutu output sekolah,

${ }^{7}$ Rohiat, Manajemen Sekolah; Teori Dasar dan Praktik, Bandung: Refika Aditama, 2008, hal. 58

8 Suharsimi Arikunto, Dasar-Dasar Evaluasi Pendidikan. Jakarta: Bumi Akasra. 2013, Cet ke-2. hal.5

9 Imam Machali dan Ara Hidayat, The Hand Book Education Management, Jakarta: Kencana, 2016, hal. 366 dapat dijelaskan bahwaoutput sekolah dikatakan berkualitas/bermutu tinggi jika prestasi sekolah, khusunya prestasi belajar siswa, menunjukkan pencapaian yang tinggi dalam: (1) prestasi akademik, berupa nilai ulangan umum, UNAS, karya ilmiah, lomba akademik, dan (2) prestasi non-akademik, seperti misalnya IMTAQ, kejujuran, kesopanan, olah raga, kesnian, keterampilan kejujuran, dan kegiatankegiatan ektsrakurikuler lainnya. Mutu sekolah dipengaruhi oleh banyak tahapan kegiatan yang saling berhubungan (proses) seperti misalnya perencanaan, pelaksanaan, dan pengawasan. ${ }^{10}$

Kualitas adalah gambaran dan karakteristik menyeluruh dari barang atau jasa yang menunjukan kemampuannya dalam memuasakan kebutuhan yang ditentukan atau yang tersirat. Efektifitas adalah ukuran yang menyatakan sejauh mana sasaran (kuantitas, kualitas, dan waktu) yang telah dicapai. Produktifitas adalah hasil perbandingan antara output dan input. Baik output dan input adalah dalam bentuk kuantitas. Kuantitas input berupa tenaga kerja, modal, bahan, dan energi. Sedangkan kuantitas output berupa jumlah barang atau jasa yang tergantung pada jenis pekerjannya. Output Sekolah dapat dikatakan berkualitas dan bermutu tinggi apabila prestasi pencapaian siswa menunjukan pencapaian yang tinggi dalam bidang: (1) Prestasi akademik (academic achievement), berupa nilai ujian semester, ujian nasional, karya ilmiah, dan lomba akademik. (2) Prestasi non akademik (non-academic achievement), berupa kualitas iman dan takwa, kejujuran, kesopanan, olahraga, kesenian, keterampilan, dan kegiatan-kegiatan ekstrakulikuler lainnya. ${ }^{11}$

\footnotetext{
${ }^{10}$ http://www.kompasiana.com, Paradigma Input dan Output Pendidikan, diakses tangal 16 Maret 2017

11 Imam Machali dan Ara Hidayat, The Hand Book Education Management, 2016, Jakarta: Kencana, hal. 369
} 
Berkenaan dengan output dalam pendidikan dapat disimpulkan bahwa output pendidikan adalah hasil atau tolak ukur dari sebuah proses pendidikan yang akan menentukan baik, buruk atau berhasil atau tidak berhasil dari pelaksanaan program pendidikan itu sendiri.

\section{Analisis Mutu Pendidikan SD/MI Unggulan Ash-Shiddiqiyyah-3 Purworejo}

SD/MI Unggulan Ash-Siddiqiyyah-3 bertempat di Desa Dukuhdungus Kecamatan Grabag Kabupaten Purworejo. Sekolah/Madrasah tersebut rintisan dari Lembaga Pendidikan Yayasan AshShiddiqiyyah Purworejo, yang didirikan sejak tahun 2013, dan telah memiliki siswa sampai kelas $4 .^{12}$

Untuk gambaran secara umum SD/MI Unggulan Ash-Siddiqiyyah-3, mari kita lihat profil lembaga tersebut yang mencakup komponen Input, Proses, dan Output. Input lembaga yang meliputi: Sumber daya manusia, Sumber daya lainnya, Perangkat lembaga, dan Harapanharapan.

\section{Sumber daya manusia}

Madrasah tersebut dipimpin oleh Bapak Sofyan Rizali Zain sebagai Kepala Sekolah. Pendidik secara keseluruhan sementara ini yaitu: (Muh Fadil Mutahor, Lia Purwanti, Azizah Nadhif, Ummu Athiyah, Eny Munifatul Baroroh, Nikmah Waliyah). Tenaga kependidikan sementara ini ditangani oleh semua Guru. Konselor pendidikan ditangani oleh wali kelas masingmasing. Karyawan yang ada sebanyak satu orang yaitu Penjaga Sekolah. Peserta didik dari kelas satu sampai kelas empat sebanyak 54 siswa.

12 Hasil Wawancara dengan Nikmah Waliyah, Guru SD/MI Unggulan Ash-Siddiqiyyah-3, pada tanggal 05 April 2017.
2. Sumber daya lainnya

Peralatan yang tersedia yaitu: ruang kelas yang kondusif, sarana ibadah (mushola), lapangan olah raga, sarana bermain, alat peraga edukatif, kamar mandi, laboratorium komputer dan internet, ruang UKS. Perlengkapan: yang tersedia sampai saat ini yaitu: Transportasi untuk antar jemput siswa yang tidak menetap di Pondok Pesantren. Uang atau sumber dana selama ini bersumber pada BOS dan sumber dana Yayasan.

3. Perangkat lembaga

Perangkat lembaga yang berupa Struktur Organisasi Sekolah sementara ini belum ada. Untuk Peraturan Perundang-Undangan selama ini berpedoman pada UU Sisdiknas. Perangkat Deskripsi Tugas tertera pada SK pembagian tugas dari Kepala Sekolah. Perangkat Rencana dan Program tetera pada administrasi rencana dan program Kepala Sekolah.

4. Harapan-harapan

Visi yang diusung oleh Madrasah tersebut yaitu mempersiapkan generasi bangsa yang Agamis, Cerdas, Terampil, dan Berakhlakul karimah. Kemudian Madrasah memiliki Misi mewujudkan SDM berkualitas, terampil, handal, professional, jujur, dan memiliki akhlakul karimah. Meningkatkan keterpaduan wawasan ilmu pengetahuan umum dan khasanah ilmu keagamaan. Menyiapkan lulusan yang produktif, adaptif, kreatif agar mampu berkompetisi dan mampu mengembangkan jiwa mandiri serta tanggap dengan dunia global. Dan Madrasah memiliki Tujuan untuk mempersiapkan dan mewujudkan generasi bangsa yang Agamis, Cerdas, Terampil, dan Berakhlakul karimah 
sesuai dengan perkembangan dunia global. ${ }^{13}$

Tindak lanjut dari Input adalah Proses, terkait dengan Proses pendidikan di SD/MI Unggulan Ash-Siddiqiyyah-3, komponen yang harus terpenuhi yaitu: Pengambilan keputusan, Proses pengelolaan kelembagaan, Proses pengelolaan program, Proses belajar mengajar, dan Proses monitoring \& evaluasi.

Pengambilan keputusan pada madrasah tersebut dilakukan dengan sistem musyawarah, namun keputusan akhir tetap dengan system pondok yaitu demokrasi terpimpin, pertimbangan sepenuhnya diserahkan kepada Kyai. Lalu untuk proses pengelolaan kelembagaan diserahkan kepada seluruh civitas madrasah, dipimpin oleh kepala madrasah. Dalam proses pengelolaan program diserahkan kepada seluruh civitas madrasah, dipimpin oleh kepala madrasah. Kemudian proses belajar mengajar dilakukan di ruang kelas yang kondusif. Terahir yaitu proses monitoring \& evaluasi diserahkan pada Departemen Pendidikan Nasional dan Lembaga Pendidikan Yayasan Ash-Shiddiqiyyah Berjan Purworejo. ${ }^{14}$

Selanjutnya setelah analisis Proses yaitu analisis Output. Output Sekolah/Madrasah dapat dikatakan berkualitas dan bermutu tinggi apabila prestasi pencapaian siswa menunjukan pencapaian yang tinggi dalam bidang: (1) Prestasi akademik (academic achievement), berupa nilai ujian semester, ujian nasional, karya ilmiah, dan lomba akademik. (2) Prestasi non akademik

13 Hasil Wawancara dengan Nikmah Waliyah, Guru SD/MI Unggulan Ash-Siddiqiyyah-3, pada tanggal 05 April 2017.

${ }^{14}$ Ibid. (non-academic achievement), berupa kualitas iman dan takwa, kejujuran, kesopanan, olahraga, kesenian, keterampilan, dan kegiatan-kegiatan ekstrakulikuler lainnya. ${ }^{15}$

Prestasi akademik dalam bidang karya ilmiah dan ujian nasional di SD/MI Unggulan Ash-Siddiqiyyah-3 belum maksimal, karena karya ilmiah dalam tingkat Sekolah Dasar memang belum dikembangkan, dan ujian nasional memang belum pernah mengikuti karena siswa masih sampai tingkat empat. Namun prestasi akademik lain yang berupa nilai ujian semester dan lomba akademik di madrasah tersebut sudah baik, dibuktikan dari nilai ujian semester dan prestasi lomba akademik. ${ }^{16}$

Prestasi non akademik yang berupa kualitas iman dan takwa, kejujuran, kesopanan, olahraga, kesenian, keterampilan, dan kegiatan-kegiatan ekstrakulikuler lainnya di Madrasah tersebut sudah bisa dikatakan baik. Karena dalam setiap proses pembelajaran dan proses penanaman karakter, pendidik tidak bosannya menggembleng siswanya untuk menjadi generasi bangsa yang sehat, agamis, cerdas, terampil, dan berakhlakul karimah sesuai dengan visi SD/MI Unggulan Ash-Siddiqiyyah-3. ${ }^{17}$

Dari penjabaran tentang Input yang meliputi (Sumber daya manusia, Sumber daya lainnya, Perangkat lembaga, dan Harapan-harapan), Proses Pendidikan meliputi (Pengambilan keputusan, Proses pengelolaan kelembagaan, Proses pengelolaan program, Proses belajar mengajar, dan Proses monitoring \& evaluasi), dan Output Pendidikan meliputi (Prestasi akademik dan prestasi non akademik) di SD/MI Unggulan AshSiddiqiyyah-3 Dukuhdungus Grabag

15 Imam Machali dan Ara Hidayat, The Hand Book Education Management, 2016, Jakarta: Kencana, hal. 369

16 Hasil Wawancara dengan Nikmah Waliyah, Guru SD/MI Unggulan Ash-Siddiqiyyah-3, pada tanggal 05 April 2017.

${ }^{17}$ Ibid., 
Purworejo. Maka penulis dapat menyimpulkan bahwa, Madrasah tersebut belum bermutu tinggi, karena belum terpenuhinya komponen ketiga unsur mutu pendidikan yaitu: Input, Proses, dan Output secara lengkap.

\section{KESIMPULAN}

Pendidikan Islam pada hakikatnya memiliki tujuan tidak saja sebagai pencetak lulusan sebagai Human Investmen, akan tetapi sebagai usaha penyadaran kepada peserta didik agar sadar akan posisinya sebagai Kholifatullah fil Ardhi. Selanjutnya pendidikan Islam memiliki mandat dan tanggung jawab untuk menciptakan para lulusannya sebagai penggerak kegiatan sosial keagamaan yang dapat menampilkan warna keislaman yang moderat dan bersikap bijak terhadap penyelesaian berbagai problem kemasyarakatan.

Pendidikan Islam dituntut untuk terus beradaptasi dan mengantisipasi perkembangan ilmu dan teknologi, sehingga tetap relevan dan kontekstual dengan kebutuhan zaman. Mengingat dinamika global yang telah menempatkan ilmu dan teknologi sebagai pilar utama dalam berbagai aspek dalam bidang kehidupan.

Peningkatan mutu pendidikan Islam harus mencakup tiga unsur yaitu: input, proses, dan output pendidikan. Input pendidikan adalah segala sesuatu yang harus tersedia karena dibutuhkan untuk berlangsungnya proses. Segala sesuatu itu berupa sumberdaya manusia dan sumber daya non manusia demi berlangsunnya proses pendidikan.

Proses pendidikan merupakan berubahnya sesuatu menjadi sesuatu yang lain. Dalam pendidikan, proses yang dimaksud adalah proses pengambilan keputusan, proses pengelolaan kelembagaan, proses pengelolaan program, proses belajar mengajar, dan proses monitoring dan evaluasi, dengan catatan bahwa proses belajar mengajar memiliki tingkat kepentingan tinggi dibandingkan dengan proses-proses yang lain.

Output pendidikan di Sekolah/Madrasah dapat dikatakan berkualitas dan bermutu tinggi apabila prestasi pencapaian siswa menunjukan pencapaian yang tinggi dalam bidang: (1) Prestasi akademik (academic achievement), berupa nilai ujian semester, ujian nasional, karya ilmiah, dan lomba akademik. (2) Prestasi non akademik (non-academic achievement), berupa kualitas iman dan takwa, kejujuran, kesopanan, olahraga, kesenian, keterampilan, dan kegiatan-kegiatan ekstrakulikuler lainnya.

Adapun temuan penting dalam penelitian ini adalah SD/MI Unggulan AshShiddiqiyyah-3 di Purworejo belum dapat dikatakan sebagai madrasah/sekolah yang bermutu. Sebab, belum terpenuhinya ketiga komponen mutu pendidikan, yaitu: input, proses, dan output secara keseluruhan.

\section{DAFTAR PUSTAKA}

Ali, Nizar, dan Syatibi, Ibi, 2009, Manajemen Pendidikan Islam, Bekasi: Pustaka Ishfahan

Arifin, Zaenal, 2010, Evaluasi Pembelajaran, Bandung: Rosdakarya

Arikunto, Suharsimi, 2006, Dasar-dasar Evaluasi Pendidikan, Jakarta: Bumi Aksara, Cet. 6

Daryanto, 2009, Evaluasi Pendidikan, Jakarta: Rineka Cipta

Fatah, Nanang, 2013, Landasan Manajemen Pendidikan, Bandung: Remaja Rosdakarya

Ihsan, Hamdani, dan Ihsan, Fuad, 2007, Filsafat Pendidikan Islam, Bandung: Pustaka Setia, Cet. 3

Machali, Imam, dan Hidayat, Ara, 2016, The Hand Book Education Management, Jakarta: Kencana 
Rohiat, 2008, Manajemen Sekolah; Teori Dasar dan Praktik, Bandung, Refika Aditama

Sudiyono, Anas, 2005, Pengantar Evaluasi Pendidikan, Jakarta: PT RajaGrafindo Persada, Ed. 1, Cet. 5

Sudjada, Nana, 2012, Penilai Hasil Proses Belajar Mengajar, Bandung: Remaja Rosdakarya

Sujana, Djudju, 2008, Evaluasi Program Pendidikan Luar Sekolah, Bandung: Remaja Rosdakarya

Syaefudin, S. (2018). IMPLEMENTASI MANAJEMEN MUTU TERPADU (MMT) PADA LEMBAGA PENDIDIKAN ISLAM (Studi Kasus di MI Unggulan Ash-Siddiqiyyah 3 Purworejo). Jurnal Pendidikan Agama Islam. https://doi.org/10.14421/jpai.20 18.152-09

www.kompasiana.com, Paradigma Input dan Output Pendidikan, diakses tangal 16 Maret 2017

Yusuf, Tayibnapis, Farida, 2008, Evaluasi Pendidikan dan Instrumen Evaluasi, Jakarta: Rineka Cipta 